\title{
TITIK-TITIK SYNDROME: KONDISI PENDERITA POSSESSION SYNDROME SEBAGAI SUMBER PENCIPTAAN TARI
}

\author{
Fetri Ana Rachmawati \\ Program Pascasarjana Institut Seni Indonesia Yogyakarta \\ Email: fetrirachmawati15@gmail.com
}

\begin{abstract}
ABSTRAK
Pengalaman sebagai penderita Possession Syndrome yang diderita penulis dijadikan dasar permasalahan dalam karya tari ini. Melalui metode riset kualitatif yang digunakan untuk mengumpulkan hasil riset tentang possession syndrom yang berada di sekitar lingkungan penulis. Kemudian berlanjut ketahap penentuan tema, judul, dan proses penciptaan. Tema yang dipilih untuk karya tari ini yakni "kondisi penderita Possession Syndrome". Pemilihan tema ini juga mengacu pada permasalahan di masyarakat yang selalu mengaitkan Possession Syndrome dengan hal-hal mistik, sehingga yang terjadi perlakuan yang didapat oleh penderita memberi dampak yang semakin buruk bagi tubuh penderita tersebut. Karya tari ini menggunakan sepuluh penari perempuan, jumlah sepuluh hanya untuk keperluan komposisi, dipilih penari perempuan karena penderita Possession Syndrome lebih dominan perempuan. Dalam karya ini akan dimunculkan teror - teror audio dan teror visual yang hadir dari lighting, kehadiran teror audio visual memberi dampak ketidak nyamanan bagi penonton hal ini merupakan gambaran dari kondisi yang dialami penderita "Possession Syndrome"
\end{abstract}

Kata Kunci: Kondisi tubuh, Possession Syndrome, perlakuan.

\section{ABSTRACT}

The experience of suffering from a Possession Syndrome suffered by the author was then used as a basis for problems in this dance work. Through qualitative research methods that are used to collect research results on the Possession Syndrome that is around the author's environment. Then it continues to determine the theme, title, and process of creation. The theme chosen for this dance work 
is "patient's condition Possession Syndrome". The selection of this theme also refers to problems in society that always associate Possession Syndrome with mystical matters, so that what happens to the treatment obtained by sufferers has an increasingly bad impact on the body of the sufferer. This dance works using ten female dancers, the number ten only for the purposes of the composition, selected dancers woman for Possession Syndrome sufferers more dominant female.In this work an audio and visual terror will emerge that comes from lighting, the presence of audiovisual terror has an impact on the audience's inconvenience, this is a picture of the conditions experienced by sufferers of "possession syndrome".

Keyword: Condition, Possession Syndrome, treatmen.

\section{PENDAhULUAN}

Gordon Graham dalam bukunya Karina Anjani mengatakan (1997:55, 2014) bahwa karya seni merupakan pernyataan sadar dari senimannya yang mengandung elaborasi, posisi, dan doktrin. Begitu juga dengan karya seni tari yang banyak mengandung pernyataan sengaja dan secara sadar yang diungkapkan dalam karya tari oleh penulis. Baik karya tari tradisional, kreasi, dan kontemporer.

Seni tari berkaitan dengan ekspresi jiwa yang dengan kesadarannya sendiri menciptakan bentuk-bentuk dengan tubuh sebagai media utamanya. Pada mulanya seniman jarang menjadikan hal tersebut sebagai bahan pembicaraan, walaupun mereka kerap kali memiliki gagasan-gagasan yang baik dan jujur untuk menerangkan apa hakikat atau makna dari yang ia kerjakan (Read, 1993: 3).
Dunia tari yang dijalani beberapa tahun belakangan membuat pemahaman tentang seni tari memiliki perkembangan. Sampai akhirnya, disadari bahwa tari mengajarkan sebuah kejujuran diawali dari hati kemudian dituangkan kedalam sebuah estetika rasa, bukan hanya tentang estetika gerak atau gerak yang indah tetapi lebih jauh dan lebih dalam lagi, yakni tentang rasa.

Membahas tentang rasa, mengutip pernyataan dari I Wayan Dibia dalam bukunya yang berjudul Tari Komunal (2006: 19), kualitas tarian seseorang ditentukan oleh tiga hal: kedalaman emosi, kematangan jiwa, dan kemampuan tubuh. Ketiga kualitas tarian tersebut mudah untuk kita dapatkan apabila sesuatu yang pernah kita alami bahkan sering kita alami, yang sangat dekat dengan diri kita. Oleh karena itu, mencoba mengingat kembali 
apa yang dekat dengan diri. Salah satu yang menonjol dalam ingatan adalah kesurupan atau Possession Syndrome, karena Possession Syndrome merupakan pengalaman yang pernah dialami.

Mengalami Possession Syndrome atau kesurupan berawal dari umur 15 tahun ketika duduk di bangku SMA. Awalnya kejadian tersebut hanya sesekali terjadi, kemudian ketika umur 19 tahun tingkat sugestibilitas makin meningkat di mana ketika hanya mendengar lengkingan suara perempuan dan juga lagu-lagu yang dipercaya berbau magis, di antaranya lagu Boneka Abdi yang berasal dari Jawa Barat dan lagu Nina Bobo.

Mengambil istilah dari ilmu psikologi maka digunakan Possession Syndrome untuk menyebut kata lain dari kesurupan. Menurut Dadang Hawari yang dikutip dari wordpressss, Possession Syndrome merupakan reaksi kejiwaan yang dinamakan reaksi disosiasi. Reaksi yang mengakibatkan hilangnya kemampuan seseorang untuk menyadari realitas di sekitarnya. Sedangkan Kaplan mengatakan (1994: 651) "trance atau Possession Syndrome merupakan suatu perubahan kesadaran dan menunjukkan penurunan responsivitas terhadap stimulus lingkungan". Possession Syndrome ditandai dengan hilangnya sebagian ataupun seluruh kesadaran dan digantikan dengan ingatan masa lalu ataupun identitas sementara yang dilanjutkan dengan keadaan amnesia, atau individu tidak mengingat kejadian selama gangguan. (Cardena, 1992: 400, dalam Deborah , et. al, 2014)

Possession Syndrome atau kesurupan yang dialami seringkali muncul karena adanya stress. Awal mula stress biasanya dimulai dari masa remaja yang merupakan masa peralihan. Menurut Berk dalam bukunya Development Through The LifeSpan (2017:13), remaja seringkali stress berkepanjangan karena pengaruh biologis maupun lingkungan. Selain itu remaja putri mengalami stress dua kali lebih besar dari pada laki-laki. Maka diperlukan dukungan psikologi dari orang-orang terdekat bagi individu untuk menangani stres, jika tidak maka individu dengan keadaan stres dapat masuk dalam keadaan Possession Syndrome. Hal ini disebabkan oleh tingkat sugesti berkembang dengan cepat, sesuatu yang tadinya merupakan stimulus kecil dalam keadaan ini dimanifestasikan menjadi stimulus besar.

Menurut Roughet (1985: 3), trance menunjukkan bahwa ia sesuai dengan disposisi psychophatologis bawaan dalam sifat manusia. Pernyataan yang disampaikan Roughet kemudian dipahami bahwa Possession Syndrome pada dasarnya ada pada diri manusia tapi bagaimana manusia yang mengelola alam bawah sadarnya. 
Disimpulkan dari pernyataan beberapa para ahli dan juga pengalaman bahwa Possession Syndrome merupakan luapan emosi yang berlebihan dampak dari kejadian buruk yang terekam oleh alam bawah sadar, karena manusia tidak dapat mengontrol alam bawah sadarnya.

Proses Refleksi diri menjadi salah satu cara penulis untuk merumuskan tahapantahapan Possession Syndrome. Disadari bahwa ketika mengalami Possession Syndrome saat dirinya dalam keadaan stres, keadaan fisik lemah, dan memiliki problematika yang belum teratasi. Selain itu, beberapa orang yang pernah ditemui juga mengungkapkan bahwa gangguan yang pernah dialaminya dapat terulang kembali.

Melalui pengalaman diri dan beberapa orang yang berbagi cerita, ditemukan bahwa ketika seseorang mengalami Possession Syndrome, ia tidak memiliki kesadaran akan diri sendiri, dapat berteriak-teriak, menangis, hingga melakukan hal-hal di luar dari kebiasaan. Hal tersebut selaras dengan teori Gibert Roughet yang mengungkapkan bahwa terdapat dua kondisi dalam Possession Trance, yaitu simptom dan behavioral. Simptom merupakan permulaan kondisi individu, seperti gemetar, bulu kuduk berdiri, pingsan, jatuh, lesu, kejang, mulut berbusa, dan sebagainya. Sedangkan behavioral merupakan kondisi yang menunjukkan hal-hal luar biasa, seperti berjalan di atas bara tetapi kaki tidak melepuh, memegang ular berbisa tetapi tidak tergigit, berbicara berbagai bahasa yang tidak pernah dipelajari, dan sebagainya.

Tahapan-tahapan Possession Syndrome dirumuskan berdasarkan pengalaman dan pengamatan ialah sebagai berikut. Tahap awal yang dialami merupakan perubahan gejala fisik yang dirasakan seperti bahu terasa berat, kepala tiba-tiba pusing, kaki terasa lemas dan lain sebagainya. Kemudian berkembang menjadi perubahan emosi yang berubah secara tiba-tiba, drastis, dan tidak menentu. Hal ini yang menyebabkan orang berpandangan bahwa seseorang sedang dirasuki oleh makhluk halus, karena perubahan emosi dan sikap di luar kebiasaaan yang orang-orang ketahui setiap harinya. Beberapa orang yang berada di sekitar biasanya langsung memegang dan memijat bagian tubuh seperti ujung kaki, jari-jari tangan, tengkuk, dan pundak. Menurut keyakinan mereka bagian-bagian tubuh di atas merupakan titik-titik ke luarnya makhluk halus tersebut. Hal ini yang kemudian menyebabkan kondisi fisik setelah terjadi Possession Syndrome lebih terasa sakit, dan lemas. Tahapan terakhir yang dialami yakni hilang kesadaran sepenuhnya. Alam bawah sadarnya sudah menguasai keseluruhan tubuh dan fikiran. Pada tahap ini seseorang tidak sadar dengan apa yang dilakukan dan orang lakukan terhadap dirinya. Setelah sadarkan diri sudah berada di tempat 
yang berbeda dan dengan orang-orang yang berbeda dari ketika masih sadarkan diri.

Pernyataan mengenai tahapan penderita mengalami Possession Syndrome diperkuat oleh pendapat Frigerio dikutip dari wordpressss yang menyatakan ada tiga tahapan yang dialami orang kesurupan. Pertama disebut irradiation, di mana subjek tetap menyadari dirinya tetapi ada perubahan yang dirasakan pada tubuhnya. Kedua being diside, subjek berada dalam dua keadaan yang berbeda, namun ada sebagian yang dialami disadarinya. Tahap ketiga disebut incorporation, subjek sepenuhnya tidak ingat apa yang terjadi.

Selanjutnya penulis juga memiliki pengalaman menangani orang yang mengalami Possession Syndrome. Ketika hal tersebut terjadi, akan mengawasi perilaku penderita agar tidak melakukan suatu hal yang dapat merugikan dan menyakiti diri sendiri, kemudian terus menerus melakukan komunikasi dengan penderita sampai dirasakan perubahan emosi yang mulai membaik, terus berkomunikasi kembali sampai emosi penderita sudah baik, setelah itu diberikan air minum kepada penderita karena meluapkan emosi di luar dari kebiasaan dapat menguras banyak tenaga. Penderita Possession Syndrome membutuhkan waktu untuk meluapkan emosi yang tertahankan. Akan tetapi mayoritas dari orang-orang ketika hal ini terjadi membawa ke dukun, orang pintar, dan tabib. Bukan membawanya ke psikiatri ataupun dokter. Hal tersebut terjadi karena orang-orang mengaitkan Possession Syndrome dengan hal yang berbau magis. Hal ini yang awalnya dipahami dan yakini bahwa dirinya sedang diganggu, dirasuki, ataupun dikuasai makhluk halus. Keyakinan ini diperkuat oleh doktrin dari orang-orang sekitar.

Untuk mengetahui apa yang dirasakan dan dialami para penderita Possession Syndrome, diteliti dengan menggunakan metode kualitatif. Hasil dari riset kualitatif yang akan dijadikan landasan untuk menciptakan sebuah karya tari. Penggunaan riset kualitatif karena riset ini merupakan kajian dari jenis materi empiris. Riset kualitatif merupakan kajian berbagai studi dan kumpulan berbagai jenis materi empiris, seperti studi kasus, pengalaman personal, pengakuan introspektif, kisah hidup, wawancara, dan lain-lain. (Septiawan, 2010: 5, dalam Yudiaryani, et.al, 2017)

Pertama yang dilakukan merefleksikan diri sendiri secara kritis, kemudian mengamati dan mewawancari orang-orang di sekitar yang mengalami Possession Syndrome. Riset ini tidak hanya terfokus pada keadaan atau kondisi tubuh pada saat terjadi hal tersebut dan setelah terjadi. Selain itu mengulik kepribadian orangorang yang mengalami hal tersebut.

Kesimpulan dari pengalaman empiris dan pengamatan orang-orang di sekitar yang 
mengalami hal tersebut keadaan tubuh itu terjadi karena dampak dari luapan emosi yang ke luar dari biasanya. Antara tubuh dan alam bawah sadar saling berkaitan dan saling memberi dampak, ketika tidak dapat mengontrol emosi dan alam bawah sadarnya maka terjadilah Possession Syndrome yang nantinya berdampak pada keadaan tubuh. Selain itu juga dilihat dengan cara penanganan terhadap penderita Possession Syndrome yang kurang tepat dapat memperburuk kondisi fisiknya dan memberi dampak ketidaknyamanan bagi penderita. Garis besar dari hasil riset kualitatif yang dilakukan bahwa Possession Syndrome memberi dampak terhadap fisik dan juga psikis.

Hasil penelitian tentang penderita Possession Syndrome menjadi landasan untuk menciptakan sebuah karya tari yang diberi judul "Titik-titik Syndrome". Tema tari yang berasal dari pengalaman empiris akan mempermudah untuk mengungkapkan pendapat dan membedah bagaimana mempresentasikan apa yang dirasakan penderita Possession Syndrome kedalam karya tari.

Hasil karya tari ini nantinya dipengaruhi oleh kondisi penulis, kondisi sosial, dan kondisi lingkungan. Kondisi fisik dan psikis berpengaruh ketika menciptakan sebuah karya, kondisi sosial yang mendukung karya tari ini akan berpengaruh besar terhadap karya tari, dan kondisi lingkungan seperti tempat pementasan akan berpengaruh besar terhadap karya tari. Karya tari ini melibatkan beberapa orang penderita Possession Syndrome untuk mempermudah menguatkan konsep karya tari ini.

\section{PEMBAHASAN}

\section{A. Landasan Penciptaan}

Proses penciptaan karya baru sebenarnya tidak bisa lepas dari sesuatu proses kreatif dalam usaha untuk mewujudkan ide atau imajinasi yang diperoleh dalam penginderaan ke dalam suatu bentuk karya nyata. Untuk menuju proses kreatif diawali dengan adanya landasan penciptaan berupa teori-teori yang menyangkut proses kreatif dan permasalahan yang ada.

Teori Trans Disosiatif merupakan teori yang digunakan dalam karya tari ini. Trans Disosiatif merupakan perubahan yang bersifat temporer dalam hal kesadarannya atau lemah /hilangnya perasaan identitas diri (senses of personal identity) tanpa kemunculan identitas baru (DSMR-IV-TR, 2000). Teori ini memberikan pemahaman tentang lemahnya kesadaran manusia yang dikuasai oleh manusia itu sendiri, yang seharusnya individu dapat mengontrol diri sendiri. Dalam teori ini membuka pemahaman tentang hilangnya kesadaran bukan melulu berganti dengan identitas baru dalam dirinya. Penggunaan teori yang ada adalm bidang psikologi ini untuk memperkuat penulis dalam tahap penelitian. 
Dalam buku Trilogi Seni: Penciptaan, Eksistensi, dan kegunaan. Yang diciptakan oleh Soedarso Sp pada tahun 2006 terdapat beberapa pendapat tentang seni dan ekspresi yang kemudian dijadikan penulis sebagai teori mengenai ekspresi. Terdapat argumen-argumen dari para ahli seperti Jacques Maritain, George Santayana, dan juga Eugene Veron mengenai seni. Dominasi dari pendapat para ahli mengatakan tentang seberapa dalam seni yang lahir dari jiwa manusia bukan persoalan kesenian itu menyenangkan. Fungsi seni menurut Veron adalah mengekpresikan keseluruhan emosi manusia, yang menyenangkan ataupun yang menyedihkan, hal ini berkaitan dengan pengalaman empiris mengenai pengalaman menyedihkan sebagai rangsang awal. Pernyataan veron ini menguatkan untuk percaya bawha seni bukan selalu tentang sesuatu yang menyenangkan, sesuatu yang berhubungan dengan keindahan semata.

Tahap penciptaan karya tari "Titik-titik Syndrome" menggunakan buku Koreografi: (Bentuk-Teknik-Isi). Isi dalam buku ini yang dibutuhkan untuk menciptakan karya tari ini bagaimana mengolah gerak, ruang, dan waktu, yang dijadikan dasar dalam menciptakan. Selain itu dalam buku ini membahas tentang pendekatan koeografi sebagai konteks isi (content) artinya melihat bentuk atau sosok tarian yang nampak secara empirik struktur luarnya (surface structure) senantiasa mengandung arti dari "isi" (content) atau "sturktur dalamnya" (deep structur). (Y.Sumandyo, 2014:55). Hal ini, berhubungan dengan karya tari yang disampaikan yang menitikberatkan kepada isi (content), bukan semata-mata tentang gerak yang indah.

Penulis merespons unsur tari dapat dikembangkan lebih komprehensif, dengan dipertimbangkan secara logis untuk mewujudkan, keindahan, keseimbangan, keselarasan dari pola penggarapan. Dikatakan bahwa tari memiliki kemampuan yang begitu luas, berdasarkan dari kreasi setiap individu yang berbeda.

Dari pengalaman bergelut di dunia seni tari kemudian memilih permasalahan empiris yang dijadikan dasar dalam menciptakan karya tari ini, karena karya seni bisa tumbuh dan berkembang jika diawali dari kegelisahan yang muncul dari diri sendiri, dan hasil mengamati orang-orang disekeliling sebagai penderita Possession Syndrome.

Karya ini dibuat menurut hasil riset, imajinasi, penafsiran, dan kreatifitas. Dimulai dari merefleksikan pengalaman sendiri kemudian melihat orang-orang di sekitar yang pernah menderita Possession Syndrome. Tata cara tersebut tidak dikemas secara naratif dan berceritra. Hal ini yang menjadikan dasar dari pemikiran nantinya dituangkan ke dalam karya 
tari. Adapun tahapan landasan penciptaan dalam karya tari ini sebagai berikut:

\section{Rangsang Tari}

Suatu rangsang dapat didefinisikan sebagai sesuatu yang membangkitkan fikir, atau semangat, atau mendorong kegiatan. Rangsang bagi komposisi tari dapat berupa auditif, visual, gagasan, rabaan atau kinestetik (Smith, 1976:20, dalam Suharto, 1985) Munculnya sebuah ide penciptaan karya seni dipicu oleh sebuah rangsang, yang mendorong koreografer untuk mencipta dan sebagai pijakan bagi koreografer ialah rangsang.

Rangsang awal dalam karya ini yakni rangsang gagasan (ideasional), rangsang gagasan muncul dari sebuah cerita, kejadian, dan juga peristiwa. Kejadian di mana pengalaman ketika menjadi penderita dan melihat peristiwa orang ketika mengalami Possession Syndrome.

\section{Tema Tari}

Suatu yang mendasari atau sebagai pokok pikiran yang mendasari karya tari yang diciptakan yakni tema. Berdasarkan rangsang tari tema yang dipilih dalam karya ini adalah "kondisi penderita Possession Syndrome" Dari tema tersebut akan diaplikasikan ke dalam karya dengan bentuk dramatik dan menurut representasi penulis.

Pemilihan tema ini juga mengacu pada permasalahan di masyarakat yang selalu mengaitkan Possession Syndrome dengan hal- hal magis sehingga yang terjadi perlakuan yang didapat oleh penderita memberi dampak yang semakin buruk bagi tubuh penderita tersebut.

Diharapkan dengan pemilihan tema untuk karya ini dapat memeberi efek positif bagi para penderita Possession Syndrome dan memberi pemahaman bagi orang-orang tentang Possession Syndrome atau lebih dikenal dengan istilah kesurupan.

3. Judul

Karya ini nantinya diberi judul "Titiktitik Syndrome". Judul ini diambil untuk memudahkan penonton dalam menerjemahkan karya tari tersebut, selain itu juga pemilihan bahasa yang diambil dari ilmu psikologi ini untuk membuang kesan magis yang melekat, nantinya penonton tidak menyalahartikan karya tari ini. Penggunaan kata titik-titik pada judul sebagai pemicu penonton berfikir syndrome apa yang dimaksud pada karya tari ini.

Penggunaan kata titik diawal kalimat sebelum Syndrome juga memiliki makna sebagai akhir pencarian bagi diri sebagai penderita Possession Syndrome yang telah menemukan titik temu dari permasalahan tersebut. Pengalaman ini yang dibagikan dalam karya tari ini.

\section{Bentuk dan Cara Ungkap}

Bentuk dan cara ungkap merupakan salah satu cara mengungkapkan maksud dan makna sebuah karya tari baik secara langsung maupun tidak langsung. Maka dari itu bentuk 
dan cara ungkap merupakan salah satu pondasi yang kuat dalam menciptakan karya tari. Ketika penonton kurang memahami tentang bentuk karya tari yang kita sajikan maka ada kekeliruan.

Tipe tari dalam dunia tari ada beberapa macam tipe tari di antaranya tipe tari studi, tipe tari dramatik, tipe tari dramatari, dan lainnya. Dalam karya tari ini tipe tari yang digunakan yakni dramatari, karena memusatkan perhatian pada sebuah kejadian atau suasana yang tidak menggelarkan ceritra (Smith, 1976:27, dalam Soeharto, 1985) Setiap kejadian dan suasana yang ditangkap mengenai Possession Syndrome diungkapkan dengan menggunakan tipe tari dramatik. Cara penyajian Pada karya ini menggunakan mode penyajian nonrepresentasional (simbolik). Dalam karya ini selain penonton menyaksikan penyajian yang disajikan, juga mengajak emosi penonton untuk merasakan konflik yang terdapat dalam karya tari ini. Bagaimana emosi yang dirasakan penderita Possession Syndrome yang diwakili oleh penari dapat tersampaikan dengan baik kepada penonton. Gerak-gerak yang muncul dari penari merupakan simbol-simbol dari apa yang dilakukan penderita maupun perlakuan di sekitar penderita.

\section{B. Metode Penciptaan Tari}

1. Refleksi Diri

Ide yang muncul berawal dari pengalaman diri kemudian timbul suatu kegelisahan. Untuk mencari solusi dari kegelisahan tersebut dicoba merefleksikan diri sendiri, mencoba membuka memori lama, dan kejadian apa yang dialami sebelum terjadi Possession Syndrome. Akhirnya dapat disimpulkan bahwa emosi yang meluap dan tindakan yang di luar kebiasaan itu disebabkan emosi atau rasa yang tidak tersampaikan dan ketika ada suatu beban yang sedang dipikirkan.

Memori-memori terdahulu di masa kecil juga salah satu faktor penunjang hal itu terjadi. Memori yang sangat lekat diingat yakni masalah-masalah internal keluarga. Hidup dengan kedua orang tua dan kakak laki-laki yang terpaut umur sepuluh tahun, masalah yang pertama yang muncul dalam keluarga yakni bagaimana ketika masa kecil tidak pernah rukun dengan kakak laki-laki hal ini dikarenakan kekecewaan ketika adik yang lahir berjenis kelamin perempuan bukan laki-laki. Kedua perlakuan negatif ayah terhadap ibu yang selalu disaksikan. Terakhir perlakuan ayah yang selalu mengekang dan membatasi keinginan dan kebebasan. Faktor-faktor tersebut yang menyebabkan diri menjadi seorang pribadi yang pendiam, tidak banyak bicara, takut dengan orang asing, lebih banyak 
menyendiri, dan cenderung pribadi yang introvert.

Pemahaman tersebut kemudian dapat dijadikan kisi-kisi untuk mencari solusi ketika mengalami Possession Syndrome pada saat ini, dengan cara tidak membenci kejadian masa lalu yang buruk, mengontrol alam bawah sadar dan lebih banyak bercerita tentang hal yang dapat menimbulkan beban pikiran.

\section{Metode Kualitatif dan Kuantitatif}

Metode kualitatif secara umum merupakan penelitian tentang penelitian yang bersifat deskriptif dan menggunakan analisis. Metode ini merupakan lanjutan dari refleksi diri yang digunakan dalam karya ini. Setelah penulis memahami diri sendiri kemudian melihat orang lain kemudian beranjak kepada penelitian kualitatif dimana penulis mengadakan angket dengan beberapa orang yang pernah mengalami maupun melihat penderita Possession Syndrome kemudian penulis menyimpulkan dan mengambil garis besar dari berbagai persepsi.

Objek yang menjadi sumber wawancara penulis terdiri dari 34 orang dari berbagai profesi, penulis menggunakan kata kesurupan pada saat proses angket.

Beberapa pertanyaan yang penulis ajukan Possession Syndrome diantaranya:

a. Apakah kamu pernah mengalami kesurupan ataupun melihat orang kesurupan?
21 dari 34 menjawab mereka pernah merasakan kesurupan

13 dari 34 menjawab pernah melihat orang kesurupan

b. Apa hal utama yang dirasakan orang kesurupan?

11 orang menjawab melamun

23 orang menjawab perubahan fisik seperti bahu terasa berat, kaki lemas, kepala berat, mata kunang-kunang, tengkuk terasa berat, dan badan terasa lemas.

c. Apakah kamu sadar jika kamu akan mengalami kesurupan ataupun melihat orang lain akan kesurupan ?

16 orang menjawab sadar

5 orang menjawab tidak sadar

8 orang menyadari orang yang disekitar akan kesurupan

5 orang tidak menyadari orang disekitar akan kesurupan

Apa yang dirasakan ketika kesurupan ? 12 orang mengatakan mereka sadar apa yang terjadi tetapi tidak dapat mengontrol apa yang dirinya lakukan.

9 orang mengatakan tidak sadar dengan apa yang terjadi.

13 orang menjawab tidak mengerti apa yang dirasakan.

d. Apa yang dirasakan tubuh setelah mengalami kesurupan?

21 orang mengatakan tubuh terasa lemas, sakit, dan cape. 
e. Bagaimana pendapatmu terhadap perlakuan orang yang memperlakukan kamu ketika kesurupan ?

12 orang mengatakan biasanya orang disekitar memegang ataupun memijat bagian tubuh seperti tengkuk, ujung kaki, telapak tangan.

f. Apakah kondisi tubuh kamu sedang tidak enak badan atau sedang kelelahan ketika akan kesurupan ?

21 orang berpendapat ketika dirinya akan kesurupan kondisi mereka sedang kelelahan, dan sedang ada masalah yang dihadapi membuat beban pikiran.

g. Apakah kamu memiliki banyak fikiran ketika akan kesurupan?

21 orang menjawab iyah.

h. Apakah kamu sering memendam ketika kamu marah ?

28 orang menjawab iyah.

i. Apakah kamu punya cerita buruk di masa kecil sampai remaja yang sampai saat ini kamu masih mengingatnya ?

24 orang menjawab memiliki cerita buruk pada masa kecil sampai remaja.

\section{Metode Alma Hawkins}

Pada buku Alma Hawkins yang diterjemahkan oleh Y. Sumandyo Hadi yang berjudul Mencipta Lewat Tari menyimpulkan pada dasarnya proses penciptaan tari mengandung beberapa tahapan, kemudian penulis hanya menggunakan beberapa tahapan menurut kebutuhan karya tari Possession Syndrome.

\section{a. Eksplorasi}

"Eksplorasi adalah suatu proses penjajagan sebagai pengalaman untuk menanggapi objek dari luar, atau aktivitasnya mendapat rangsang dari luar" (Sumandyo,2003:95). Eksplorasi diawali dengan berimajinasi, mencoba merasakan, dan menafsirkan yang bersangkutan dengan tema kemudian melakukan proses di studio.

Tahapan Selanjutnya yakni melakukan Proses studio, proses ini dilakukan dengan penata memberi motivasi gerak bersama penari mencoba mengeksplorasi tubuh. Hal ini dilakukan agar penata mengetahui karakter tubuh dari setiap penarinya karena setiap tubuh penari memiliki karakter tubuh yang berbeda. Mengeksplor kekuatan para penari.

b. Komposisi

Hambatan dan kekurangan pada tahap sebelumnya coba diperbaiki pada tahap ini untuk mendapatkan alur yang jelas dan lebih terstruktur. Adapun bentuk karya terbagi dalam empat adegan:

\section{1) Adegan 1}

Bagian satu berisi teror audio dan visual yang membuat penonton tidak merasa nyaman untuk mendengar dan melihat, hal ini penggambaran perasaan penderita Possession Syndrome, dan lebih kepada kejadian-kejadian buruk yang dialami dan disaksikan yang sampai 
saat ini masih tetap disimpan di alam bawah sadarnya, faktor ini salah satu yang menyebabkan terjadianya hal tersebut. Unsur yang ditonjolkan pada adegan ini lebih kepada menampilkan unsur pendukung seperti tata cahaya, iringan, dan visual lainnya, untuk menimbulkan kesan ilusi masuk ke masa lalu. Rasa tidak nyaman yang dirasakan penonton dari karya ini merupakan tujuan pada bagian ini, hal ini interpretasi dari memori yang buruk yang dialami di masa lampau. Kemudian penari masuk dengan membawa lampu senter sebagai media penerangan, motivasi gerak dan rasa yang disampaikan dalam adegan ini yakni paranoid.

\section{2) Adegan 2}

Hasil dari pengalaman dan pengamatan terhadap penderita Possession Syndrome penulis menyimpulkan adatiga fase yang dialami ketika hal itu terjadi, diawali dengan fase awal dimana badan terasa lemas, punggung terasa berat, kepala pusing, dan lain sebagainya. Gejala yang dirasakan lebih kepada perubahan kondisi fisik. Fase kedua pada bagian ini hilangnya setengah kesadaran, penderita sadar dengan keadaan sekitar tetapi tidak dapat mengontrol tubuhnya sendiri, lebih kepada rasa ketika kita tidak dapat melakukan apa yang kita inginkan terhadap diri kita sendiri. Fase ketiga dimana pelaku hilang kesadaran sepenuhnya, tidak lagi bisa mengingat apa yang terjadi di sekelilingnya.

\section{3) Adegan 3}

Perlakuan orang di sekitar ketika melihat penderita kadang menanggulangi dengan cara yang kurang tepat, yang menimbulkan rasa sakit yang lebih pada tubuh ketika penderita sadar. Cukup dengan menjaga penderita agar penderita tidak melakukan hal-hal yang menyakiti diri sendiri, karena tanpa ditanggulangi sebenarnya tubuh penderita ketika sadar akan terasa lemas, tenaga berkurang banyak, badan terasa nyeri, dan merasakan letih yang berlebihan, apabila ditambah dengan perlakuan orang disekitar yang menyakiti tubuh penderita.

\section{4) Adegan 4}

Sebuah karya yang berasal dari sebuah kegelisahan secara tidak langsung memberi solusi dari kegelisahan itu sendiri, yang bermanfaat untuk penulis, pendukung karya, bahkan penonton. Kegelisahan yang timbul dari diri sendiri maka penulis mencoba mencari solusi dari apa yang dia alami, yakni dengan cara merefleksikan diri, mengambil hal positif dari memori yang negatif, dan yang paling penting bagaimana kita mengontrol diri sendiri itu yang dijadikan kunci sekaligus jawaban dari kegelisahan ini. Mungkin apa yang didapat penulis bisa dijadikan acuan untuk para penonton yang mengalami hal yang sama. Dalam karya ini penari akan menari dengan menutup mata karena penulis meyakini bahwa 
mata merupakan unsur penting untuk menyeimbangkan tubuh ketika bergerak.

\section{c. Evaluasi}

Pada tahap evaluasi ini merupakan penilaian tentang kesesuaian gerak dengan tema penciptaan, tidak hanya gerak yang dapat dievaluasi aspek-aspek yang lainnya dapat menunjang konsep yang telah dibuat ikut dalam tahap ini karena tahap ini dilakukan agar karya ini dapat sesuai konsep dan diterima oleh semua pihak. Setelah melakukan penggarapan koreografi ini, penata akan melakukan evaluasi baik evaluasi dari penata itu sendiri maupun evaluasi dari pendukung lainnya.

Aspek-aspek pendukung tari seperti iringan tari, kostum, properti, dan tata cahaya, selalu berkembang sesuai dengan hasil evaluasi dari pendukung karya ini. Selain para pendukung karya ini pembimbing dari penulis karya ini juga memberikan kontribusi pada tahap evaluasi.

\section{Pematangan dan Ide Penciptaan}

Bersumber dari pengalaman empiris sebagai penderita Possession Syndrome kemudian melakukan penelitian yang pertama yakni merefleksikan diri penulis terlebih dahulu kemudian meneliti penderita lainnya bagaimana kondisi fisik dan kondisi psikis yang dialami penderita Possession Syndrome selain itu juga bagaimana perlakuan orang-orang sekitar ketika menjumpai penderita, hasil dari penelitian tersebut kemudian dijadikan ide penciptaan karya tari untuk tugas akhir.

Tahap selanjutnya yakni menentukan tema tari, ketika mengambil ide garap tentang Possession Syndrome tema yang muncul yakni adalah "kondisi penderita Possession Syndrome" baik kondisi fisik maupun kondisi psikis selain itu juga kondisi orang-orang disekitar. Pemilihan tema ini penulis lebih leluasa dalam proses penciptaan tari karena yang berdekatan diri penulis, sehingga mudah diinterpretasikan oleh penulis. Berpijak pada hal diatas maka terpilihlah tema tari tersebut untuk digunakan dalam karya tugas akhir ini.

\section{Pemilihan dan Penetapan Penari}

Dalam karya tari ini penulis menggunakan sepuluh penari yakni, Venny Agustin, Nurlilis, Putri, Yussi, Kinesti Eqi, Meidinar Adellia, Fatmawati, Nada Nurafifah, Ariesta PR, Rinjani Hanggarasih. pemilihan penari ini tidak berdasarkan fisik tapi lebih kepada pengalaman penari mengenai Possession Syndrome ataupun kesurupan yang berkaitan dengan hal magis dan juga kedekatan seringnya berproses bersama.

\section{Penetapan Iringan dan Penata Musik}

Musik merupakan unsur pendukung utama dalam karya tari pemilihan dan penetapan yang kurang tepat dapat memberi efek yang kurang baik terhadap karya tari. Diawali dengan penetapan konsep iringan yang diinginkan oleh penulis kemudian memilih penata musik yang 
karya-karyanya sesuai dengan apa yang diinginkan akhirnya memilih Gigin sebagai penata musik untuk karya tari ini. Gigin merupakan alumni dari etnomusikologi ISI Yogyakarta dan pascasarjana ISI Surakarta, pengalamnnya dalam bermusik dan karyakarya musik yang diciptakan sesuai dengan konsep yang diinginkan selain itu juga rasa tanggung jawab yang dimiliki Gigin akhirnya dengan yakin memilihnya sebagai penata musik untuk karya tari ini. Gigin memilih Ekky dan Kadek Dwi sebagai pemain. Alat-alat musik yang digunakan di antaranya:
a. Cetik
b. Gong Kecil dan dua bonang
c. Kecapi
d. Floor tom dan Rebana
e. Suling Recorder

Selain alat musik yang sudah ada, iringan karya tari ini menggunakan alat musik yang diciptakan yang memang untuk kebutuhan karya tari ini, di antaranya:

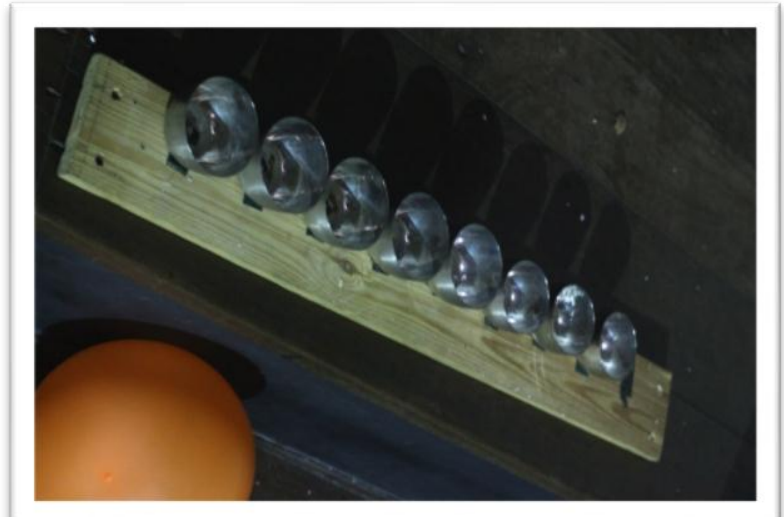

Gambar 1. Alat Musik yang dibuat untuk keperluan karya ( doc. Ody Art Studio 2019)

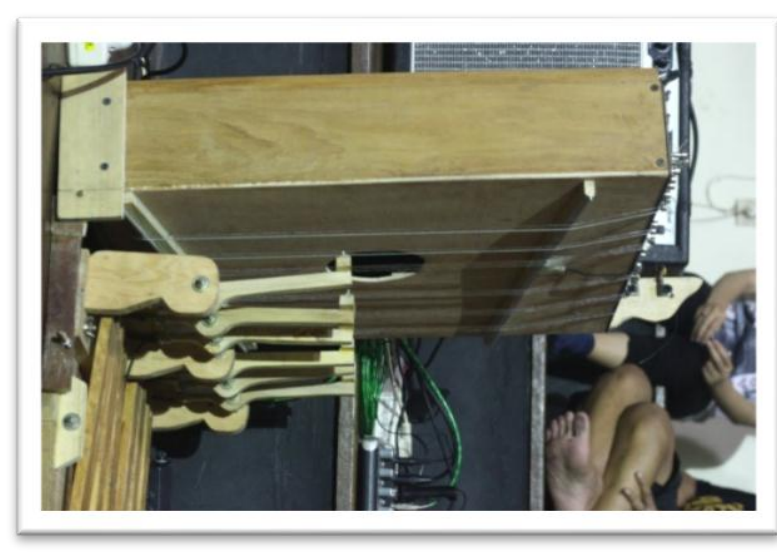

Gambar 2. Alat Musik yang dibuat untuk keperluan karya ( doc. Ody Art Studio 2019)

selain alat musik yang diciptakan sendiri dalam karya musik ini juga menggunakan barang-barang sehari-hari seperti:
a. Kipas Angin
b. Hair drayer
c. Balon
d. Gabus

Selain Gigin dipilih Septian Dwi Cahyo mahasiswa Musik di ISI Yogyakarta sebagai penata musik untuk musik MIDI. Septian memiliki pengalaman yang banyak dalam menghitung frekuensi suara di mana karyakaryanya banyak yang mempertimbangkan tentang frekuensi, hal yang membuat yakin untuk memilih Septian sebagai penata musik MIDI untuk karya ini.

\section{Pemilihan Rias dan Busana}

Rias dan busana unsur pendukung yang tidak bisa lepas dalam karya tari, tata rias menggunakan makeup korektif untuk 
memunculkan karakteristik pribadi penari tidak menjadi sosok siapapun. Tata rambut penari tidak menggunakan sanggul ataupun rambut sintetis, hanya menggunakan rambut masingmasing kemudian di ikat kuat menjadi satu. Pemilihan tata rias wajah dan rambut untuk memberikan kesan natural sehari-hari.

Dalam karya ini digunakan busana berwarna putih. Warna putih merupakan warna yang dikategorikan warna netral yang beberikan kesan kebebasan. Salah satu pesan yang ingin disampaikan dalam karya tari ini yakni tentang kebebasan seorang penderita Possession Syndrome yang bisa lepas dari hal tersebut dengan cara mengontrol alam bawah sadarnya itulah alasan penulis menggunakan warna putih untuk busana yang dikenakan penari.

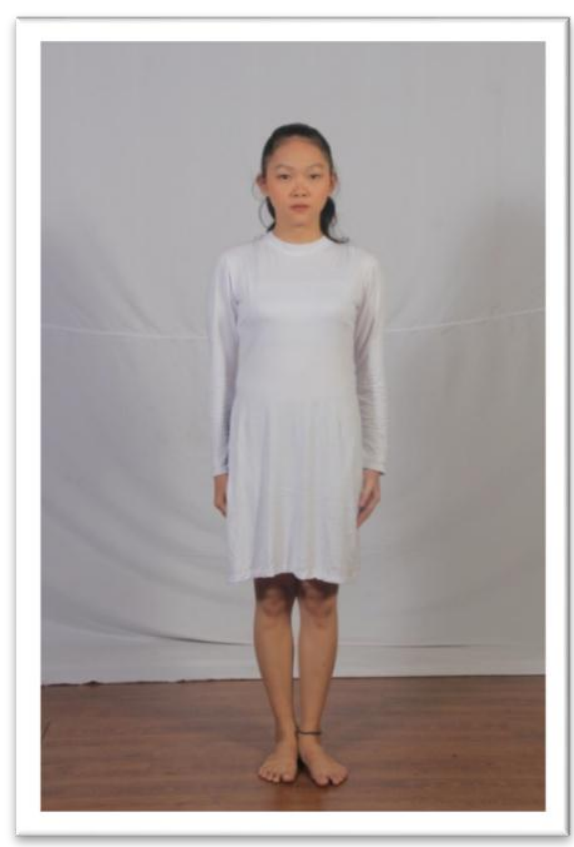

Gambar 3. Kostum tampak depan (doc.Ody Art Studio 2019)

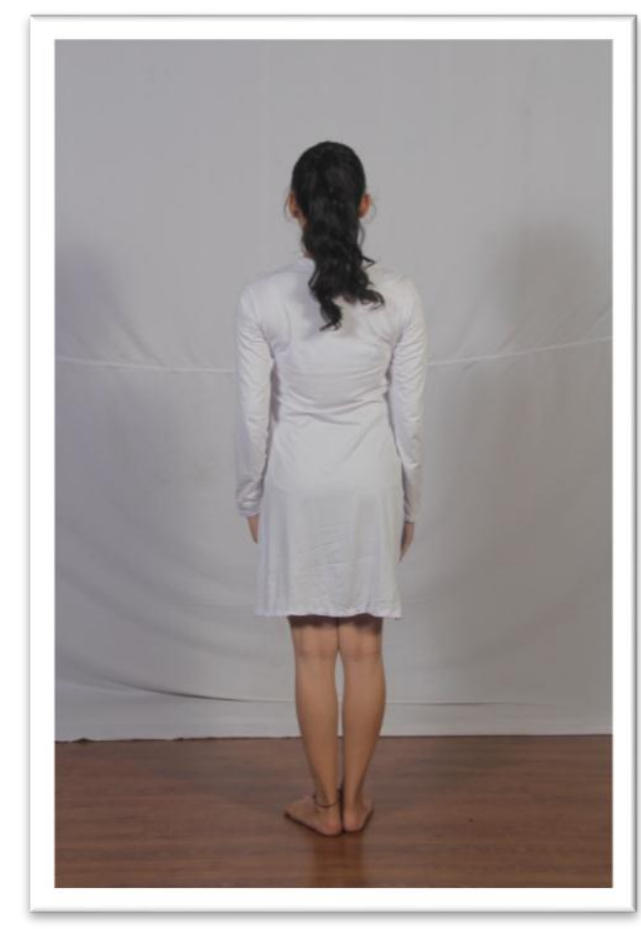

Gambar 4. Kostum tampak belakang (doc.Ody Art Studio 2019)

4. Pemilihan Ruang Pentas

Bentuk garapan yang menggunakan large group compositions membutuhkan panggung konvensional dengan bentuk persegi panjang dan luas yang cukup. Selain itu, dipilih ruang pentas yang jarak antara penonton tidak jauh dari penari. Hal ini untuk memudahkan penonton melihat dengan jelas apa yang dirasakan penari dan ikut serta merasakan apa yang disampaikan penari. Salah satu ruang pentas yang cocok dengan konsep adalah teater arena ISI Yogyakarta, di mana jarak antar penari dan penonton tidak terlalu jauh. Selain itu juga penulis dan penari sering melihat dan menggunakan teater arena maka dari itu untuk penyesuaian ruang tidak terlalu sulit. 


\section{Artistik}

Kebutuhan artistik dalam karya tari ini berupa kubus yang didalamnya terdapat karet, kubus ini akan digunakan pada adegan empat. Kubus yang berisi lintasan karet elastis ini merupakan penyimbolan dari alam bawah sadar yang menguasai para penderita Possession Syndome, bagaimana yang dapat mengontrol adalah para penderita itu sendiri.

Pembuatan kubus ini diawali dengan membeli bahan-bahan yang di lakukan pada tangga 12 Maret 2019, setelah itu proses pembuatan di lakukan dari tanggal 14-17 Maret 2019, lamanya proses pembuatan di pengaruhi oleh cuaca karena mempengaruhi pada proses pengeringan kayu yang akan digunakan. Kemudian proses pemasangan karet elastis dilakukan pada tanggal 20 Maret 2019 karena ada kekurangan bahan karet elastis kemudian dilanjutkan pada tanggal 21 Maret 2019.

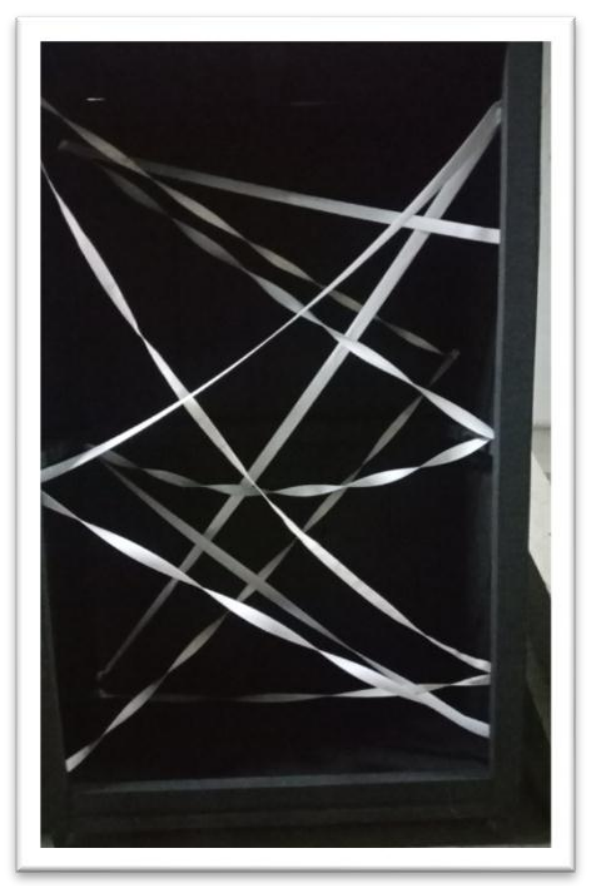

Gambar 5. Kubus dan tali elastis (doc. Fetri Ana Rachmawati 2019)

\section{Realisasi Proses dan Hasil}

\section{Penciptaan}

\section{Urutan Adegan}

Dalam realisasi proses penciptaan yang dilakukan, penulis membagi karya tari Titiktitik Syndrome menjadi beberapa segmen atau adegan. Segmen biasa dipakai dalam ranah perfilman untuk mengotak-kotakan sebuah alur cerita, terkadang adaegan satu tidak dapat langsung dimentahkan menyambung ke adegan kedua, namun konteks yang disampaikan adalah satu arah atau memiliki benang merah yang sama. Dalam penyajian karya ini dibagi menjadi beberapa adegan yakni : 


\section{a. Adegan 1}

Bagian satu berisi teror audio dan visual yang membuat penonton tidak merasa nyaman untuk mendengar dan melihat, hal ini penggambaran perasaan penderita Possession Syndrome, dan lebih kepada kejadian-kejadian buruk yang dialami dan disaksikan yang sampai saat ini masih tetap disimpan di alam bawah sadarnya. Faktor ini salah satu yang menyebabkan terjadianya hal tersebut. Pada bagian ini unsur utama yang menjadi fokus yakni tata cahaya, dan iringan, untuk menimbulkan kesan ilusi masuk ke masa lalu. Rasa tidak nyaman yang dirasakan penonton dari karya ini merupakan tujuan pada bagian ini, hal ini interpretasi dari memori yang buruk yang dialami di masa lampau.

Kemunculan delapan penari pada adegan ini dimulai pada satu menit setelah musik dan lampu strobo, penari berjalan dengan motifasi rasa ketakutan dan bentuk-bentuk penyimbolan dari penderita Possession Syndrome. Sumber cahaya pada adegan ini adalah lampu senter yang dibawa oleh masingmasing penari.

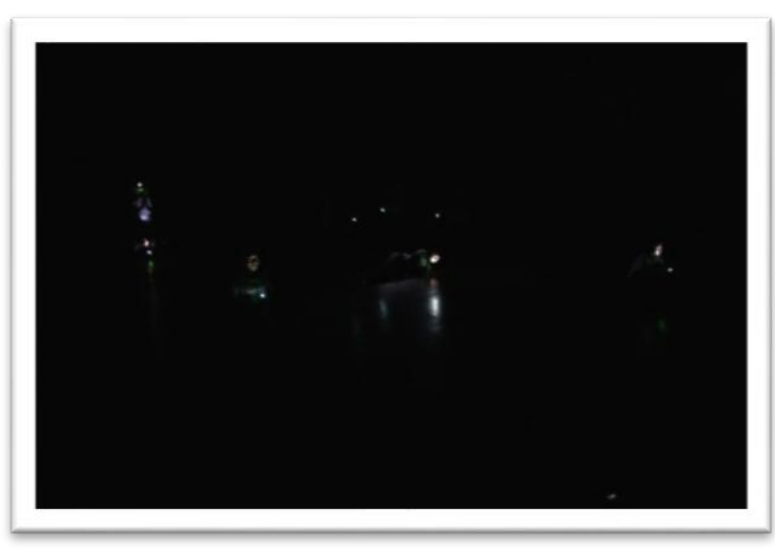

Gambar 6. Adegan 1 karya Titik-titik Syndrome (doc. Ody Art Studio 2019)

\section{b. Adegan 2}

Hasil penelitian terhadap penderita Possession Syndrome penulis menyimpulkan terdapat tiga fase yang dialami ketika hal itu terjadi. Diawali dengan fase dimana badan terasa lemas, punggung terasa berat, kepala pusing, dan lain sebagainya, gejala yang dirasakan lebih kepada perubahan kondisi fisik. Fase ini disimbolkan dengan gerakan gelengan kepala yang diulang-ulang sehingga menimbulkan rasa pusing dan mual seperti yang dirasakan penderita Possession Syndrome.

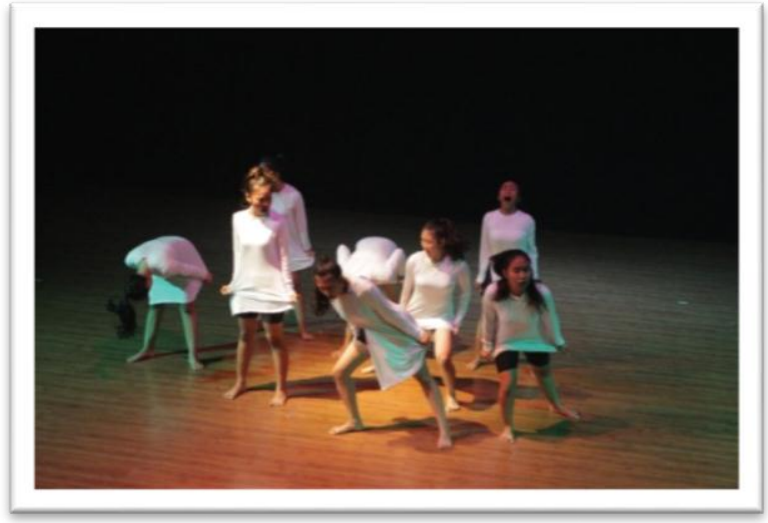

Gambar 7. Adegan gelengan kepala (doc. Ody Art Studio 2019) 
Fase kedua pada bagian ini hilangnya setengah kesadaran, penderita sadar dengan keadaan sekitar tetapi tidak dapat mengontrol tubuhnya sendiri, lebih kepada rasa ketika kita tidak dapat melakukan apa yang kita inginkan terhadap diri kita sendiri. Disimbolkan dengan satu penari duduk di tubuh ke enam penari sebagai simbol dari kepemilikan tubuh, kemudian satu penari bergerak sendiri simbol dari alam bawah sadarnya yang mengontrol.

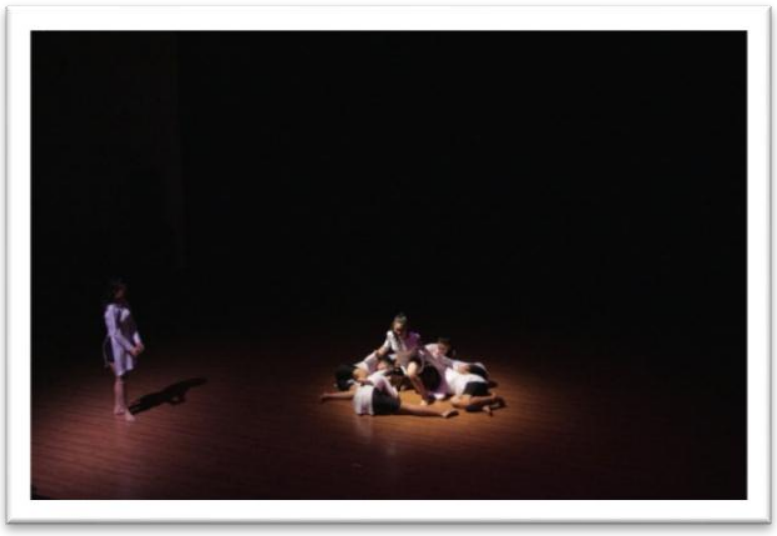

Gambar 8. Adegan dalam fase kedua (doc. Ody Art Studio 2019)

Fase ketiga dimana pelaku hilang kesadaran sepenuhnya, tidak lagi bisa mengingat apa yang terjadi di sekelilingnya. Disimbolkan dengan gerakan jatuh bangun yang dilakukan oleh delapan penari. Fase ketiga ini penari bersuara sebagai perwujudan dari kebiasaan yang dilakukan penderita Possession Syndrome ketika sudah pada fase ketiga.

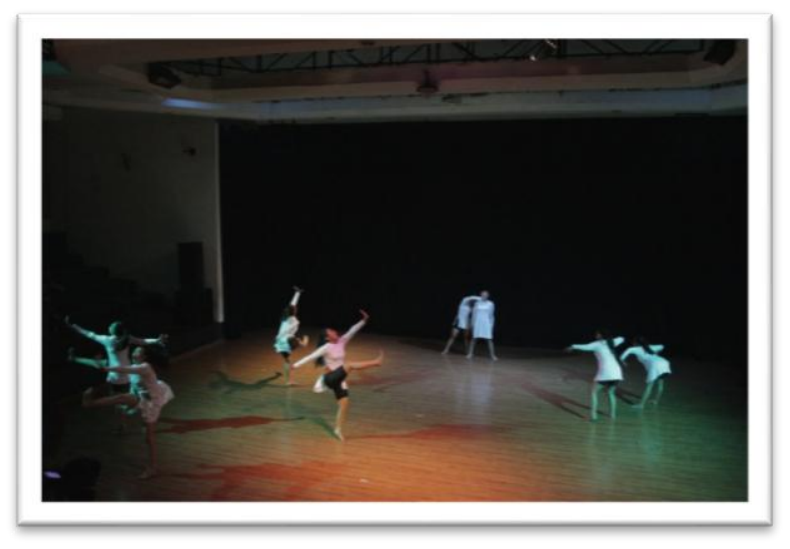

Gambar 9. Adegan gerak jatuh bangun (doc. Ody Art Studio 2019)

\section{c. Adegan 3}

Perlakuan orang disekitar ketika melihat penderita kadang menanggulangi dengan cara yang salah, yang menimbulkan rasa sakit yang lebih pada tubuh ketika penderita sadar. Cukup dengan menjaga penderita agar penderita tidak melakukan hal-hal yang menyakiti diri sendiri, karena tanpa ditanggulangi sebenarnya tubuh penderita ketika sadar akan terasa lemas, tenaga berkurang banyak, badan terasa nyeri, dan merasakan letih yang berlebihan, apabila ditambah dengan perlakuan orang disekitar yang menyakiti tubuh penderita.

Adegan ini di bagi kedalam beberapa fokus, beberapa penari sebagai simbol penderita dan sebagian lainnya sebagai orang disekitar penderita. Interaksi antar penari lebih ditonjolkan pada adegan ini seperti memegang tangan, memegang kepala, memegang tengkuk, dimana titik-titik yang bias disentuh oleh orangorang disekitar penderita. 
Klimaks dalam karya tari ini terdapat pada adegan tiga di mana dari segi gerak, emosi, dan iringan tari, lebih meningkat dari adegan satu, adegan dua, dan adegan tiga. Penonton dapat merasakan pertarungan emosi yang dialami penderita Possession Syndrome. Penulis memotivasi para penari agar penari dapat memainkan emosi bagaimana rasa sakit fisik yang diderita dan juga rasa sakit psikis.

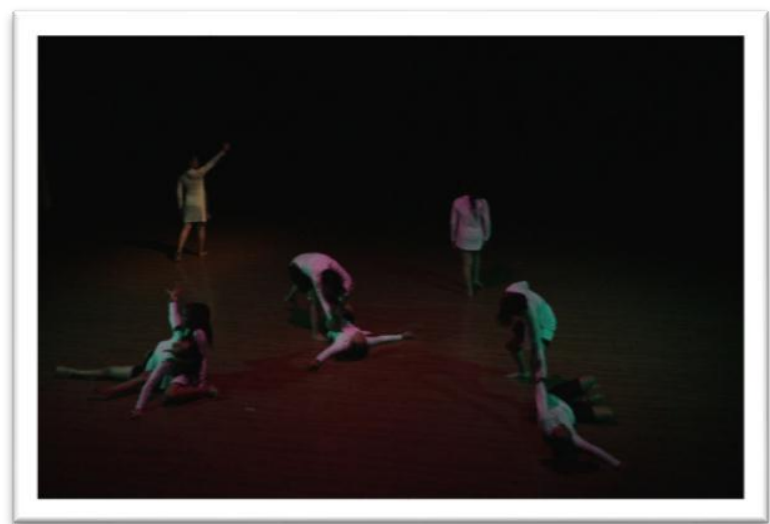

Gambar 10. Pose gerak adegan tiga (doc. Ody Art Studio 2019)

\section{d. Adegan 4}

Sebuah karya yang berasal dari sebuah kegelisahan secara tidak langsung memberi solusi dari kegelisahan itu sendiri, yang bermanfaat untuk penulis, pendukung karya, bahkan penonton. Kegelisahan yang timbul dari diri sendiri kemudian mencoba mencari solusi dari apa yang dialami, yakni dengan cara merefleksikan diri, mengambil hal positif dari memori yang negatif, dan yang paling penting bagaimana kita mengontrol diri sendiri itu yang dijadikan kunci sekaligus jawaban dari kegelisahan ini. Mungkin apa yang didapat bisa dijadikan acuan untuk para penonton yang mengalami hal yang sama.

Tiga penari muncul dari pintu penonton sebelah kiri, tiga penari lainnya muncul dari pintu penonton sebelah kanan. Empat penari sebagai simbol dari alam bawah sadar, dan dua penari diibaratkan sebagai penderita Possession Syndrome. Dua penari duduk di antara penonton sebelah kiri, dua penari lainnya duduk di antara penonton sebelah kanan, dan dua penari lagi turun ke panggung. Motivasi dari dua penari yang bergerak yakni simbol dari alam bawah sadar dan diri pribadi, gerak yang muncul yakni saling mengisi.

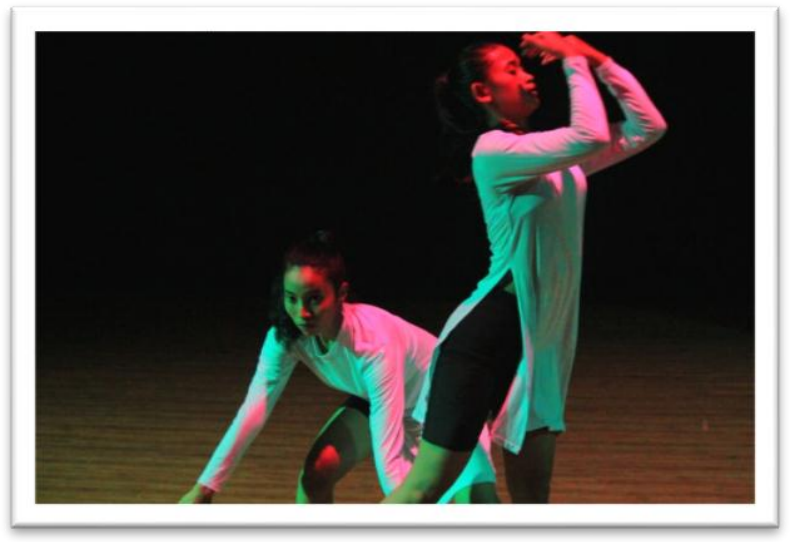

Gambar 11. Pose dua penari dalam adegan empat ( doc. Ody Art Studio 2019)

Empat penari lainnya muncul dari panggung, dua penari berada di dalam kubus dan dua penari berada di balik kubus, yang berada di panggung berjumlah empat penari, enam penari lainnya berada di tempat penonton. Pada adegan ini dua penari bersenandung lagu 
anak-anak sebagai refleksi diri bagaimana dampak dari masalah-masalah yang disimpan pada masa kanak-kanak akan tersimpan dalam alam bawah sadarnya kemudian akan diluapkan pada waktu yang tidak tentu.

Dua penari di dalam kubus simbol dari dua penderita Possession Syndrome dimana satu penderita dapat lepas dari ingatan buruk di masa lalu yang menjadi dasar hadirnya penyakit psikologi yang diderita, satu penari tidak dapat terlepas dari jeratan ingatan buruknya. Permainan emosi dua penari di dalam kubus berdampak pada enam penari lainnya. Empat penari yang berada pada kursi penonton kemudian masuk kembali ke panggung pertunjukan kemudian bergerak dengan motif yang ada pada adegan satu, adegan dua, dan adegan tiga.

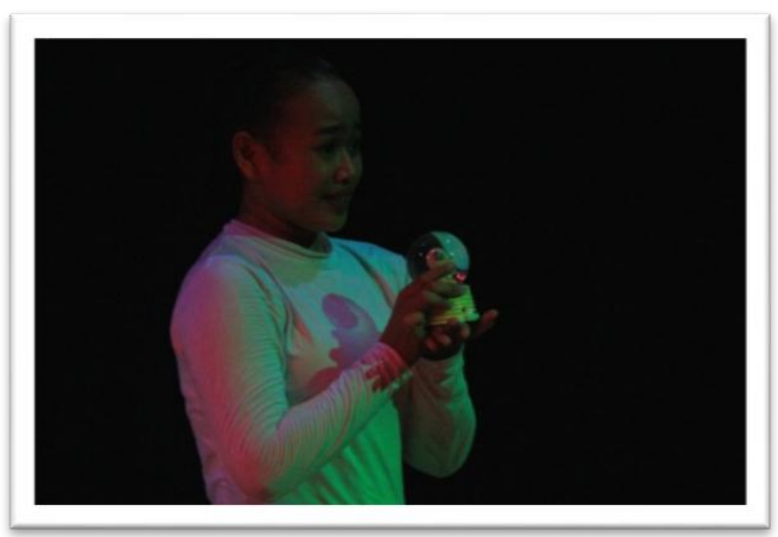

Gambar 12. Satu penari membawa properti kotak musik ( doc. Ody Art Studio 2019)

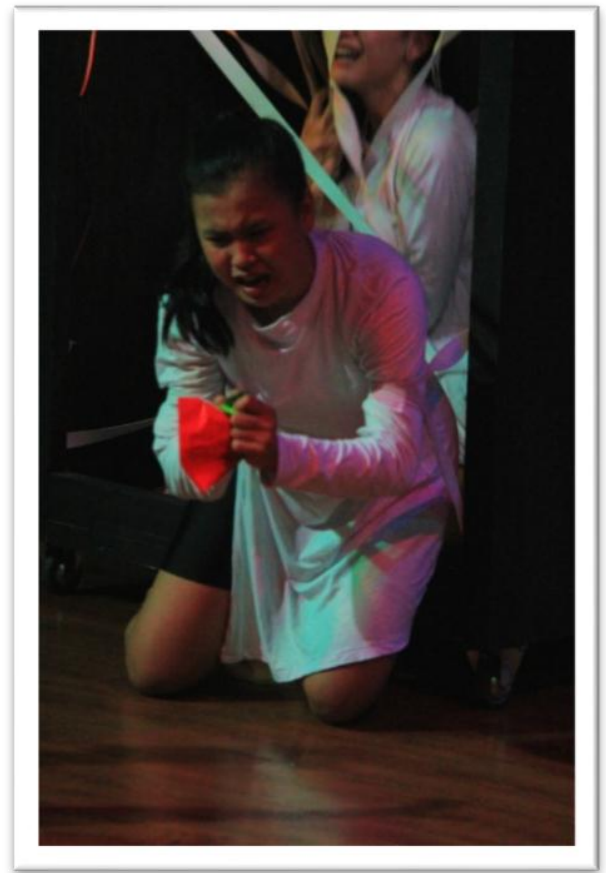

Gambar 13. Satu penari membawa kertas origami ( doc. Ody Art Studio 2019)

Satu penari membawa properti kotak musik, dan satu penari lagi membawa properti kertas origami, pemilihan kotak musik dan kertas origami sebagai penyambung emosi ke masa anak-anak di mana dua benda tersebut merupakan salah satu permainan pada masa anak-anak.

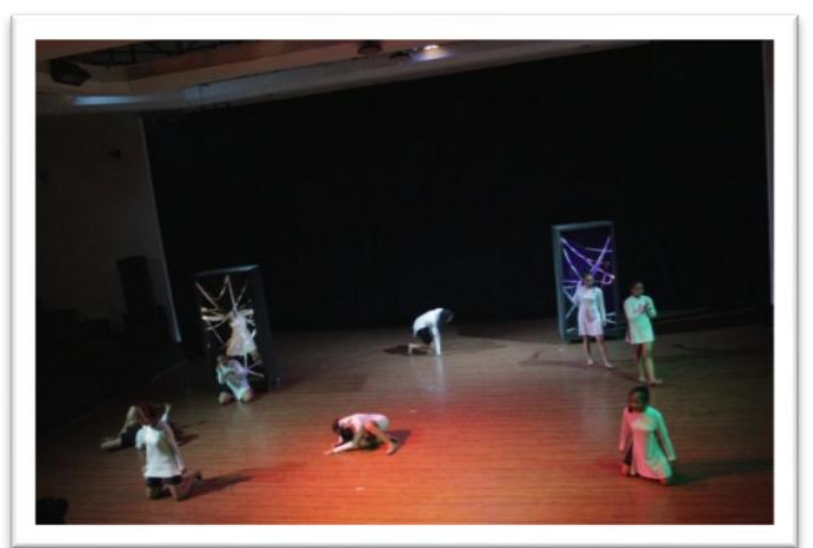

Gambar 14. Pose dari adegan terakhir ( doc. Ody Art Studio 2019) 


\section{PENUTUP}

Berawal dari masalah yang dialami kemudian mencoba untuk mencari titik terang solusi atau tata cara mengontrol masalah tersebut. Penulis mencoba berbagi melalui karya ini apa yang dirasakan penderita Possession Syndrome dari sudut pandang penderita itu sendiri, orang yang melihat, dan dari sudut pandang ilmu psiklogi.

Tahap awal adalah merefleksikan diri sendiri, kemudian berlanjut pada tahap penelitian dengan cara riset, setelah mendapatkan data-data dari lapangan dan dari beberapa orang yang memahami ilmu psikologi, penulis mencoba menyimpulkan sesuai pemahaman dan hasil penelitian penulis. Dari kesimpulan akhirnya penulis memilih tema "kondisi penderita Possession Syndrome".

Setelah tahap penelitian kemudian berlanjut pada tahap proses penciptaan. Penciptaan karya tari ini merupakan karya tari ungkapan kejujuran dari diri sendiri, karena karya seni itu tentang kejujuran tidak mengadangada. Karya tari ini diberi judul "Titik-titik Syndrome" di mana penulis menemukan titik pemecahan masalah untuk diri sendiri.

Komposisi tari ini merupakan large group composition, dengan diiringi musik live dan musik MIDI, dengan jumlah penari sepuluh orang. Karya ini dibagai dalam empat adegan dimana setiap adegan memiliki cerita yang berbeda tetapi dalam tema yang sama.

Karya tari yang berasal dari kejujuran dari diri jauh dari kata sempurna baik dari segi karya maupun tulisan, maka dari itu penulis membutuhkan saran dan kritik ataupun masukan demi kebaikan untuk penulis sendiri maupun penikmat seni khususnya seni tari. Seorang penulis dalam menciptakan karya tari bisa dikatakan sebagai pemimpin, tidak hanya mengatur penari, tetapi unsur-unsur yang terdapat pada karya tari juga harus dipikirkan. Pengalaman penulis kali ini adalah meningkatkan profesionalitas, proses kreatif, dan pola pikir. 


\section{DAFTAR SUMBER ACUAN}

\section{A. Sumber Tertulis}

Anjani, Karina. 2014. Apa Itu Musik "Kajian Tentang Sunyi dan Bunyi Berdasarkan4'33" Karya John Cage", Gajah Hidup, Tangerang.

Anjaryani AM, Rahardanto MS. 2016.Dinamika Kesurupan Patologis: Studi Kasus di Jawa Tengah, Experientia Jurnal Psikologi Indonesia, Surabaya.

Berk, E Laura. 2017.Development Through The Lifespan, Pearson Education, London.

Beidel, Fraen Benstoper \& Hersen Michel. 2014.Adult Psycopatology and Diagnosis. John Wily and Sons, Inc, Newjersey.

Darmaprawira, Sulasmi. 2002.Warna, Institut Teknologi Bandung, Bandung.

Dibia, I Wayan, et.al. 2006.Tari Komunal, Lembaga Pendidikan Seni

Nusantara, Jakarta.

Effendi, Irwansyah. 2014.Spiritualitas,

Gramedia Pustaka Pusat, Jakarta.

Hawkins, Alma M.1988.Creating Through Dance atau Mencipta Lewat Tari . Terjemahan Y. Sumandiyo Hadi.2003. Institut Seni Indonesia Yogyakarta, Yogyakarta.

Hawkins, Alma M. 1991.Moving From Within: A New Method for Dance Making atau Bergerak Menurut Kata Hati: Metode Dalam Menciptakan Karya Tari, Terjemahan. I Wayan
Dibia. 2003. Ford Foundationdan Masyarakat Seni Pertunjukan Indonesia, Jakarta.

Kaplan dan BJ Sadouk. 1994.Synopsiss of Psyciatry sevent edition, Lippincot Williams \& Wilkins a Wolters Kluwer Bussiness, Amerika.

$\begin{array}{lr}\text { Langer, } & \text { Suzanne } \\ \text { Ko02.ProblematikaSeni, } & \text { terjemahan } \\ \text { Widyanarto, SunanAmbu Press, Bandung. }\end{array}$

Martono, Hendro. 2008.Sekelumit Ruang

Pentas, Cipta Media, Yogyakarta.

Martono, Hendro. 2010.Mengenal Tata Cahaya Seni Pertunjukan, Cipta Media, Yogyakarta.

Martono, Hendro. 2012.Panggung pertunjukan dan Berkesenian, Cipta Media,

Yogyakarta.

Read, Harbert. 1993.PengertianSeniTerj. Soedarso Sp. SakuDayar Sana Yogyakarta.

Roughet, Gilbert. 1985.Music and Trance: A theory of the Relations Between Music and Possession, University of Chicago, Chicago.

Septiawan. 2017."Menulis Ilmiah Metode Penelitian Kualitatif" dalam Yudiaryani, et.al, Karya Cipta Seni Pertunjukan, Fakultas Seni Pertunjukan ISI Yogyakarta, Yogyakarta.

Smith, Jacqueline. 1976. Dance Compoositin: A practical Guide for Teacher 
atau Komposisi Tari: Sebuah Petunjuk Praktis Bagi Guru, terjemahan Ben Suharto. 1985. IKALASTI, Yogyakarta.

SM, Razali. 1999.Dissosiative Trance Disorder: A Case Report, Jurnal Eastern Jurnal Of Medicine, Turkey.

Sp, Soedarso. 2006.TRILOGI SENI Penciptaan, Eksistensi, Dan Kegunaan Seni, BP ISI Yogyakarta, Yogyakarta.

Tseng wen-shing, Streltzer Jon. 1997.Culture and Psychopatholog, Bruner, Inggris.

\section{B. Webtografi}

Frigerio. 2007.Fenomena Kesurupan Dalam Bentuk Histeria, dikutip tanggal 1 Mei 2019.

\section{https://jpfani.wordpress.com}

\section{https://books.google.co.id}

https://journal.wima.ac.id

\section{Narasumber}

Dea Agustiana, 24 tahun, pekerja seni.

Nurdella, 22 tahun, Mahasiswi.

Fatmawati, 22 tahun, Mahasiswi.

Ifa Nurfatma, 21 tahun, Mahasiswi.

Kinesti Eqi, 21 tahun, Mahasiswi.

Ozzy Azura, 23 tahun, Mahasiswi.

Bayu, 23 Tahun, alumni Psikologi UNY Yogyakarta.

Regiya, 24 Tahun, alumni Psikologi Universitas Sanata Dharma Yogyakarta.
Bella Indra Permana, 16 tahun, Mahasiswi.

Nurul Jamilah, 38 tahun, Mahasiswi.

Vandarina Sartika Sari, 23 tahun, Mahasiswi.

Adhittya Sobhitarini, 21 tahun, Mahasiswi.

Linda Dwi Puspitasari, 26 tahun, Perawat.

Dinda Wulan, 25 tahun, Mahasiswi.

Gabriela Ayang, 21 tahun, Mahasiswi.

Meidinar Adellia Sasongko, 21 tahun, Mahasiswi.

PutriSari Dwi Ningsih, 21 tahun, Mahasiswi.

Ariesta Putri R, 21 tahun, Mahasiswi.

Nasrinada, 21 tahun, Mahasiswi.

Lelly, 26 tahun, perawat.

Thiara Puspitaningtyas, 15 tahun, Siswi.

Regina, 14 tahun, Siswi.

Shenda Aprilia, 25 tahun, Mahasiswi.

Nabilla Fahilma, 21 tahun, Mahasiswi.

Crekinagara, 21 tahun, Mahasiswi.

Sheliasam, 23 tahun, Mahasiswi.

Ines Asikalani, 24 tahun, Mahasiswi.

Arica Andara, 24 tahun, Mahasiswi.

Anindita Fahma, 24 tahun, Mahasiswi.

Anugrah Mega Christina, 20 tahun, Mahasiswi.

Dwi Fitria, 20 tahun, Mahasiswi. 